\title{
GROWTH REDUCTION AND MORTALITY OF SPRUCE CAUSED BY THE EUROPEAN SPRUCE SAWFLY. GILPINIA HERCYNIAE (HTG.) (HYMENOPTERA: DIPRIONIDAE) ${ }^{1}$
}

\author{
By W. A. REEKS' and G. W. BARTER ${ }^{3}$
}

\section{INTRODUCTION}

The severe outbreak of the European spruce sawfly, Gilpinia bercyniae (Htg.), in the Gaspe Peninsula (3), continued for about ten years following its discovery in 1930. During this period other outbreaks of shorter duration developed in other regions of Quebec and in New Brunswick. The general extent of the damage has been reported in several papers $(1,2,3,5$,$) . The$ purpose of this paper is to show how the defoliation affected the growth of surviving white spruce, Picea glanca (Moench) Voss, and of black spruce, $P$. mariana (Mill.) B.S.P., and to indicate the final extent of the damage several years after the end of the outbreak.

As some of the stands investigated had been affected by a previous outbreak of the spruce budworm, Cboristoneura fumiferana (Clem.), comparisons are made of the injury caused by the two defoliators. Reference is also made to the eastern spruce beetle, Dendroctonus piceaperda Hopk., since an outbreak of this species occurred simultaneously with that of the sawfly. in the Gaspe.

This study is based principally on observations in three districts: the Cascapedia and Ste. Anne watersheds in the Gaspe Peninsula; Park Reserve Township, Kamouraska County, P.Q.; and Young's Brook, York County, N.B.

\section{METHODS}

Data on defoliation and mortality were obtained by annual observations on 73 semi-permanent cruise lines, totalling 32 acres, and on 23 permanent plots.

The lines were cruised annually at about the same points on five drainages near the centre of the Gaspe Peninsula from 1932 to 1938 . In 1938 permanent lines were established by marking every tree over 4.5 inches D.B.H. These trees were re-tallied each year until 1947. They ran across the valleys and up the slopes as far as the white spruce extended. The plots ranged in size from 0.2 to 2.8 acres and were established between 1932 and 1938 in both white spruce and black spruce types. All trees above 3.5 inches D.B.H. were numbered and examined annually. Estimates of defoliation were made from the ground and these were checked by a more critical examination of felled trees.

The increment loss of surviving trees was determined by measuring the width of annual rings of sections and cores. Thirty trees were sectioned at 10-foot intervals from 2 feet above the butt swell to about 7 feet from the

\footnotetext{
1 Contribution No. 4, Division of Forest Biology. Science Service, Department of Agriculture, Ottawa, Canada.

2 Agricultural Research Officer, Dominion Entomological Laboratory, Fredericton, N.B. 3 Technical Officer, Dominion Entomological Laboratory, Fredericton, N.B.
} 
top. Four cores were taken at breast height from each of 263 trees. The sections and cores were sanded, and measured with a micrometer fitted to a microscope. The annual growth was measured back to 1905 to check on the possible occurrence of earlier insect infestations, but the results in most cases are given only from 1925 onward. Cores of balsam fir, Abies balsamea (L.) Mill., were also measured to date previous insect outbreaks and to compare the growth with that of spruce.

Tree sections were particularly useful in dating incomplete or missing rings caused by defoliation. Since there were no missing rings in the upper crown, missing or incomplete rings in the lower sections were dated by comparison with the growth pattern of the upper sections. The dates of missing rings in the cores were determined by means of the pattern as established by section measurements. Useful guides in dating rings were the exceptionally narrow rings in 1917 and in 1918 in all regions, narrow rings at Parke Reserve in 1920 and at Young's Brook in 1921, and a wide ring in the Gaspe in 1924. Because of the poor condition of the wood and the frequency of missing rings it was found impossible to measure the growth of trees that had been killed.

The effect of defoliation on the height growth was investigated on only three trees. These were sectioned at each internode and split longitudinally to determine both height and radial growth.

It was necessary to know something of the seasonal period of growth to determine whether defoliation could affect the ring growth of the current year. The period of radial growth of two white spruce was measured near Fredericton by means of a dendrometer similar to that described by Daubenmire (9). The measurements were taken twice a week at four points at breast height, during the season of 1948. The growth of laterals and terminals was measured simultaneously on two smaller adjacent trees.

\section{Description of Study AREAS \\ Cascapedia and Ste. Anne Watersheds, Gaspe Peninsula, P.Q.}

This area had never been cut prior to the sawfly outbreak. Three types of forest were recognized for the purpose of these studies. The most important was the white spruce type, which occurred in the valleys and on the lower, gentler slopes. This type was characterized by large dominant or codominant white spruce 150 to 200 years of age, with an understory of smaller balsam fir and some black spruce. The average merchantable volume before the outbreak approached 35 cords per acre. Diameters of white spruce were as high as 25 inches at breast height.

Pure uneven-aged stands of black spruce occurred on the steeper slopes. The older trees were about 250 years old. Growth was slow in this type and diameteres ranged up to 12 inches D.B.H. Stands of black spruce also occurred over considerable areas on flat, rather poorly drained sites. This type contained a higher proportion of merchantable sized trees because growth was somewhat better than on the slopes. Diameters ranged up to 16 inches D.B.H. 
Pure stands of balsam fir were commonly found on moderately steep slopes. These were generally even-aged and had resulted from severe blowdown, which is a common occurrence on exposed sites in this region.

Periodic outbreaks of the eastern spruce beetle have occurred in the Gaspe (17), but the 1930-34 outbreak in the Cascapedia district appears to have been the most severe of these (4). Measurements of the ring growth of spruce and balsam fir show a typical pattern suggesting an outbreak of the spruce budworm between 1913 and 1918. Craighead (7) reported that light feeding of the budworm occurred throughout the Gaspe Peninsula during this period.

It is not definitely known when the sawfly outbreak commenced in this district. Ring measurements of white spruce showed that growth started to decline as early as 1925 . By the time the sawfly was discovered on the Cascapedia Watershed in 1930 over half the foliage had been eaten in some stands. Apparently the severe infestations started in the white spruce stands, where they persisted for a period of 14 or 15 years, dating from about 1925. The infestations spread to the black spruce slopes, and later to the black spruce flats where they were severe for at least 11 to eight years, respectively.

Parke Reserve Township, Kamouraska County, P.Q.

The three plots in this district contained almost equal volumes of white spruce and black spruce with smaller volumes of balsam fir and deciduous trees. The stands originated from a fire about 1875. It has been shown (18) that in this general area the spruce budworm was sufficiently numerous to cause considerable defoliation by 1913 . This was the first district outside of the Gaspe Peninsula to be seriously affected by the sawfly. Severe defoliation of spruce trees was first observed in 1933, and the outbreak extended from about 1933 to 1939, inclusive.

Young's Brook, York County, N.B.

The spruce stands on the Young's Brook study area originated from a fire about 1870 . White spruce was the predominant conifer, followed by red spruce, Picea rubens Sarg., and balsam fir. The ring pattern for the years 1913 to 1917 supports the evidence of Swaine and Craighead (18) that a severe budworm infestation occurred in central New Brunswick during this period. A very narrow ring in 1921 probably was caused by severe drought, which was reported (18) to have killed many spruce trees that had started to recover from the budworm outbreak. The sawfly reached epidemic numbers in 1936. The peak of the outbreak occurred in 1937 but the sawfly continued to cause considerable defoliation until 1939, after which date the feeding was negligible.

\section{Characteristics OF Defoliation}

Morris (16) has shown that almost 80 per cent of the feeding of the sawtly is done in the fifth larval instar. The periods of maximum feeding, therefore, correspond with the periods of greatest abundance of fifth instar larvae. They were determined from periodic larval collections and records 
of larval drop to be as follows: In the Cascapedia district, a one-generation area, August 20 to September 30; at Parke Reserve, a one-generation area with occasional second generation larvae, August I to September 15; and at Young's Brook, a two-generation area, July 15 to September 30.

White spruce is the preferred host, although red spruce and black spruce have been severely defoliated in some areas. The most extensive infestations have occurred in mature stands in which the old trees were generally the most severely defoliated. Young stands, however, have been heavily attacked. Balch (1) stated that the sawfly can completely defoliate considerable areas of young white spruce, both on abandoned pasture land where it grows in pure stands, and on old burns where it is mixed with and sometimes overtopped by intolerant hardwoods.

The larvae have a strong preference for needles over one year old. New needles of white spruce are fed upon near the end of the larval period, particularly if most of the old foliage has been eaten. The new needles of red or black spruce are never eaten as long as old foliage is available. In the following discussion it should be remembered that the amount of loss of old foliage is determined by the accumulated result of feeding in previous years, as well as in the current year. Complete defoliation normally results from several years' feeding. As Balch (2) has pointed out, it will take an average annual loss of over 17 per cent of the old foliage to cause an accumulated defoliation of more than 50 per cent. A tree could sustain an annual loss of 25 per cent for about six years before becoming completely stripped. This is based on the assumptions that the needles normally persist for seven years and that feeding is equally distributed among the needles of different ages.

The chief difference between the feeding habits of the European spruce sawfly and those of the spruce budworm lies in the preference for old foliage and new foliage respectively. The sawfly brings about a cessation of bud growth by exhausting the growing power of the branches through the gradual destruction of the needles. No buds are killed directly and no adventitious buds arise. The budworm kills many buds and young shoots by feeding on them and in severe infestations the tree is forced to repair the damage by adventitious growth. After two or three years of such feeding new growth becomes reduced and with a rising population, some feeding takes place on the old foliage after the new growth has been consumed. In general, the initial destruction of the buds and of the new foliage by the budworm is a more severe injury to the tree than the destruction of the old foliage by the sawfly. Therefore, given an equal intensity of attack, trees will withstand the latter longer than the former, and the total defoliation by the sawfly that is necessary to kill a tree is somewhat greater than it is for the budworm. A tree that retains only a very small amount of foliage can survive if this foliage, as in the case of sawfly infestations, is mostly new growth in the tip of the crown. The budworm tends to kill the crown from the top downwards, the sawfly from the bottom upwards. 


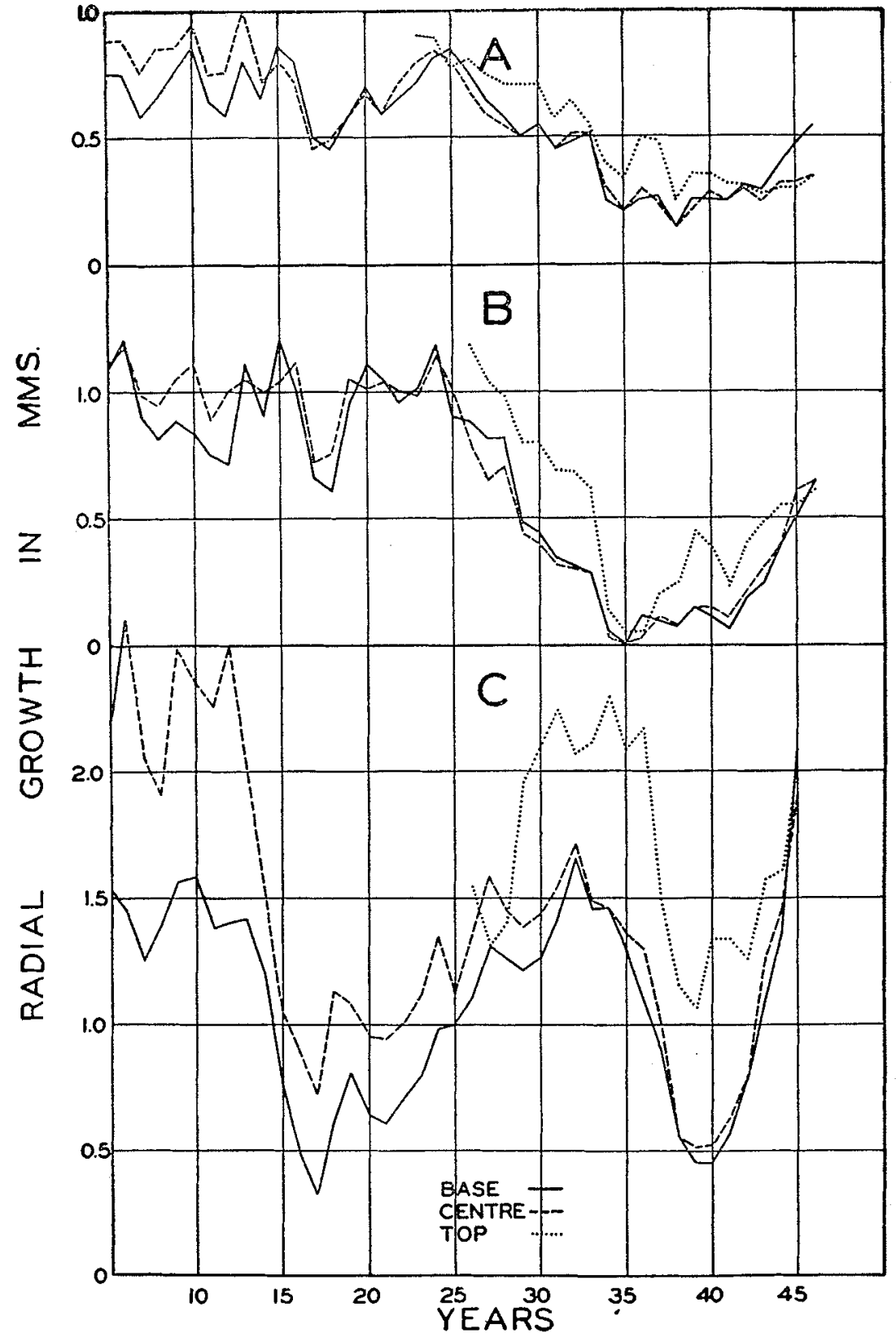

Radial growth of sections taken from dominant and co-dominant spruce trees that survived infestations of the European spruce sawfly; A black spruce, Cascapedia district, P.Q.; white spruce, Cascapedia district, P.Q.; C, white spruce, Young's Brook, N.B. 


\section{Ring Pattern}

\section{Growth Reduction of Surviving Trees}

Craighead (18) reported that the first year of severe feeding by the budworm on balsam fir resulted in severe reduction of growth in the top, less reduction near the middle, and an increase in the ring width at the base. Other observations by Evenden (10), Craighead (8), and Graham (14) suggest that this type of growth pattern is not necessarily common to all tree species following defoliation by insects or by artificial methods.

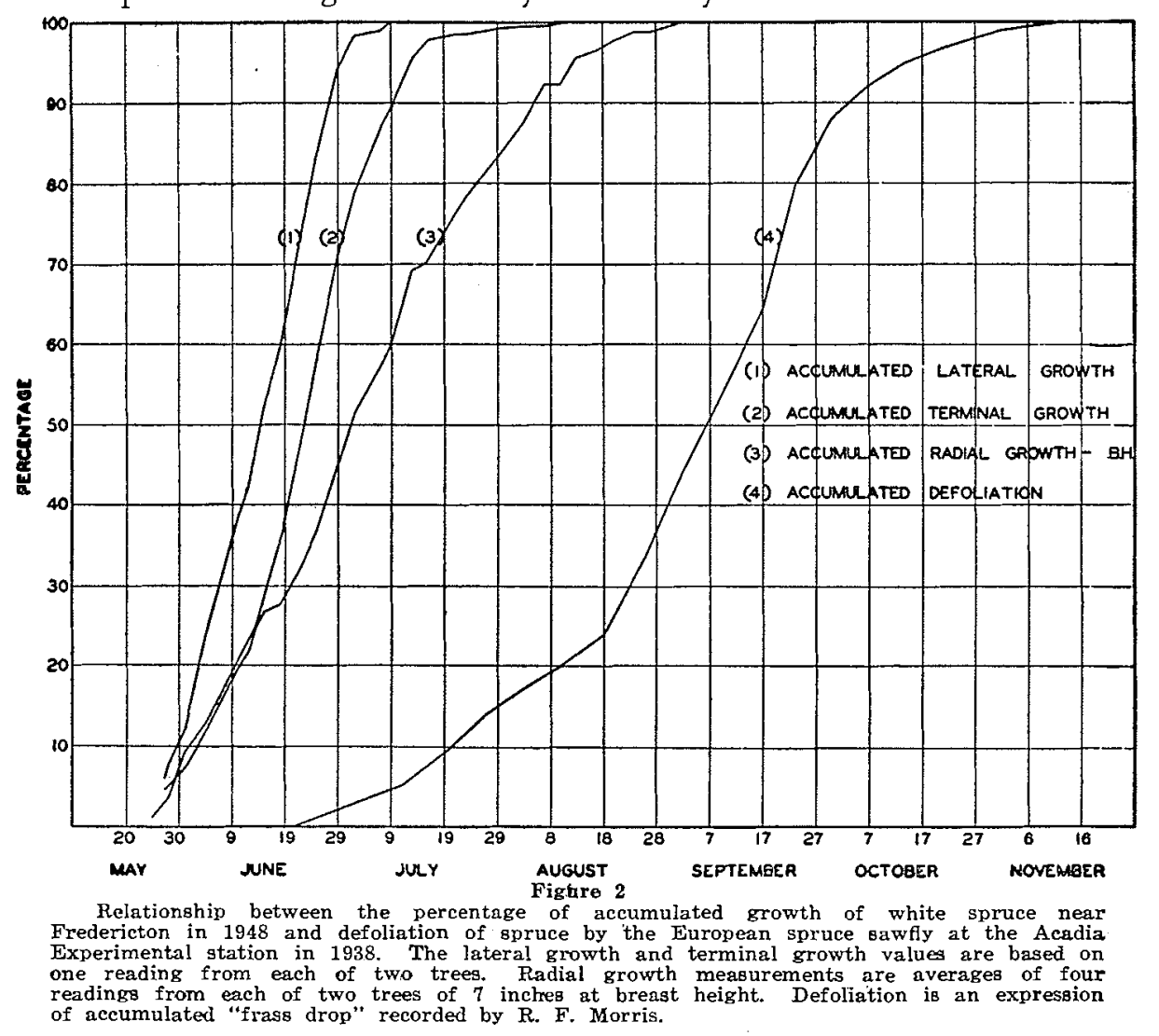

Sections from the base, middle and top of the stems of 17 dominant or co-dominant spruce trees were examined to determine whether or not the first year of attack could be dated from a characteristic ring pattern. These trees were as follows: Seven white spruce from Young's Brook, and five white spruce and five black spruce from Cascapedia. The trees from Young's Brook were most useful for this purpose because the early history of the infestation was known. The first severe attack was in 1936, when about 20 per cent of the old foliage was eaten. In the Cascapedia area the first year of attack was assumed to be 1925, and at Parke Reserve to be 1933. In 
none of these areas was there evidence of an enlarged ring at the base (Figure 1). This difference from trees that survived the budworm outbreak may be associated with the difference in type of feeding.

Measurable sawfly defoliation did not occur in New Brunswick prior to June 30 (Figure 2). By this time the percentages of accumulated growth of lateral shoots, of terminal shoots, and of radial growth at breast height amounted to approximately 95 per cent, 73 per cent, and 47 per cent, respectively. By the time 90 per cent of the radial growth had occurred, about August 5, only 18 per cent of the feeding had taken place. Although taken in different years at two different points in central New Brunswick, these records strongly suggest that sawfly defoliation cannot appreciably affect the annual ring of the current year. This is equally true of the Gaspe, where most of the feeding occurs after August 20.

Reduction in Ring Growth

During the sawfly outbreak the radial growth was reduced at all levels in the tree. This reduction was more gradual in the black spruce (Figure 1,A) and in the white spruce (Figure 1,B) that underwent the longest periods of sawfly defoliation, than in the white spruce (Figure 1,C) that were subjected to a sudden, short period of defoliation.

It was necessary to make a very careful examination of the basal sections and cores for missing or incomplete rings. The ring is narrower in the base than in the top of a normal tree, and after defoliation it tends to become most severely reduced at the base (Figure 1). The years in which missing rings occurred at breast height are given in the order of frequency of their occurence as follows: White spruce, Cascapedia, 1935, 1936, 1934, 1937, and 1938; white spruce, Parke Reserve, 1937, 1940, and 1938; white spruce, Young's Brook, none; black spruce, Cascapedia, 1938, 1935, 1934, and 1936; black spruce, Parke Reserve, none. The uppermost sections occasionally showed a few incomplete but no missing rings even in the most severely defoliated of the surviving trees. Suppression of growth in the lower stem was most striking in the white spruce in the Cascapedia district. As many as four rings were missing and up to eight were either missing or incomplete in some trees. In the white spruce at Parke Reserve up to three rings were missing and up to six were missing or incomplete. No missing or incomplete rings occurred in the white spruce at Young's Brook. As many as three missing rings and eight missing or incomplete rings occurred in the lower stem of many of the black spruce in the Cascapedia district. No rings were missing in the black spruce at Parke Reserve, but one or two were incomplete in some trees. Growth reduction at the base was more severe in spruce that recovered from sawly infestations than in balsam fir or spruce that survived the budworm outbreak. Craighead (18) reported a maximum of three rings missing in the lower stem of surviving balsam fir, and no rings were absent in the recovering spruce.

The sawfly outbreak ended rather suddenly, as reported by Balch 
and Bird (6), a virus disease of the larvae being the principal control factor. The recovery of spruce from the sawfly attack commenced about 1940 in most districts (Figures 3, 4). From 1940 onward the recovery of radial growth was more rapid in the lower and middle sections than in the top sections of the trees (Figure 1).

The data, from six plots show that reduction in radial growth was approximately proportional to reduction of the foliage, regardless of locality or species of spruce (Figure 3 ). The minimum degree of defoliation required to cause a measurable reduction in radial growth is best indicated by the plots in which the history of defoliation is most complete (Figure 3, A, D, F). The effect of defoliation on the ring width at Young's Brook is partly obscured by the general decline of growth that started in 1933. (Figure 3, A). As this decline occurred in balsam fir as well as in white spruce, part of it must be attributed to factors other than defoliation. A 20 per cent loss of old foliage in 1936 was followed by a slight reduction of ring width in 1937, and an accumulated loss of 50 per cent of the old foliage in 1937 was followed by a much stronger reduction of ring width in 1938 . This reduction must have been caused by defoliation because the growth of balsam fir increased both in 1937 and in 1938, following several years of growth decline. The growth curve of black spruce shows a similar relationship. One black spruce stand in the Cascapedia district was studied closely from 1932 when it was first severely infested (Figure 3,F). A loss of 20 per cent of the old foliage in 1932 was not followed by any appreciable reduction of the width of the ring either in 1932 or 1933. An accumulated loss of 50 per cent of the old foliage and slight feeding on the new foliage in 1933 was followed by a sharp growth reduction in 1934. Black spruce trees at Parke Reserve (Figure 3, D) had lost about 30 per cent of their foliage by 1933, and the first reduction of ring width that could be attributed to defoliation occurred in 1934. It is concluded that, with the new foliage intact, the amount of loss of old foliage necessary to cause measurable reduction of the increment is somewhere between 20 per cent and 50 per cent. The reduction does not occur until the following year.

Figure 3 provides some information regarding the length of time during which the wood growth was reduced by defoliation. In the Cascapedia district approximately 13 years of attack resulted in reduced growth for at least 17 years (Figure 3,C); at Parke Reserve about seven years of attack caused subnormal growth for about 12 years (Figure 3, B); at Young's Brook four years of severe feeding was accompanied by a period of approximately ten years of reduction in the annual ring (Figure $3, \mathrm{~A}$ ).

\section{Reduction of Height Growth}

The measurement of the reduction of height growth was confined to three trees. These were about 70 years old at the time of cutting in 1944 . The degree of growth reduction was estimated by comparing the average annual height growth from the beginning of the outbreak to 1944 with the 

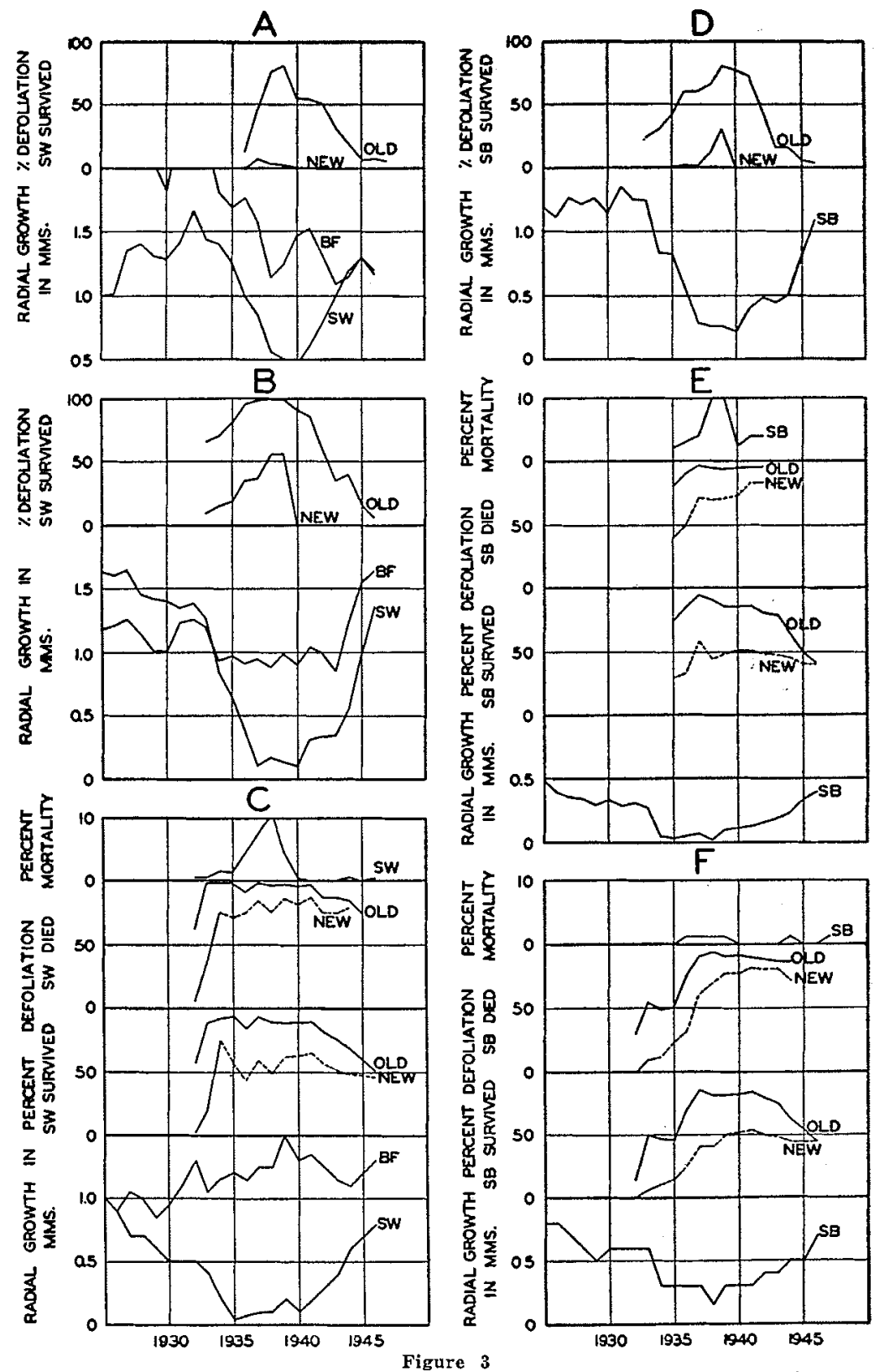

Radial growth of spruce and balsam dofoliation of dominant and co-dominant spruce tre trees, and total mortality caused by the European spruce sawfly. A, White spruce type, Young's Brook, N.B.; B, White spruce in white spruce-black spruce type, Parke Reserve, P.Q.: type, Parke Reserve, P.Q.; E, black spruce slope, Cascapedia district, P.Q. ; F, black spruce flat, Cascapedia district, P.Q. Radial growth based on the ring width of 540 cores from spruce and 160 cores from balsam fir. Old = accumulated loss of old foliage; new $=$ loss $C$, write spruce slope. Cascapedia district, P.Q., D, black spruce in white spruce-black sprace of new foliage: bf $=$ balsam fir; $8 \mathrm{w}=$ white spruce; $\mathrm{sb}=$ black spruce; broken line represents change from loss of new foliage to twig mortality. 
average growth for the 10-year period prior to the attack. The percentages of reduction in the annual height growth of the three trees were as follows: White spruce, Parke Reserve, 67 per cent; white spruce, Young's Brook, 28 per cent; and black spruce, Parke Reserve, 36 per cent. The height growth of these trees also was reduced between 1913 and 1927, as a result of budworm defoliation of trees, which were about 40 years old at the time of attack, when they are not very vulnerable.

\section{Increment Reduction in Relation to Vigour}

The ring measurements of three groups of 25 trees each were examined to determine whether vigour affected the degree of increment reduction caused by defoliation. The trees were of similar size and age, and all of them suffered defoliation of almost equal intensity. It was assumed that the trees with the widest rings before the sawfly attack were the most vigorous, and growth reduction was expressed as the quotient of:

\section{Average ring width during attack}

Average ring width before attack

where the number of years for the numerator was the same as for the denominator.

The quotient (ordinate) was plotted against the average ring width before attack (abscissa). The resulting curve was almost parallel with the abscissa, showing that the quotient was relatively constant regardless of the rate of growth before attack. Growth reduction of white spruce and of black spruce, therefore, was proportional to the rate of growth prior to the sawfly outbreak. Another test was made in which the average ring width during the period of growth recovery was used as the denominator in determining the quotient. A similar curve resulted, indicating that vigour, or rate of growth before attack, had little or no effect on the recovery of surviving trees.

\section{MORTALITY}

Extensive killing of trees was confined to the Gaspe Peninsula. In the Cascapedia district an outbreak of the eastern spruce beetle occurred during the middle of the period of defoliation, between 1930 and 1934 (4). The beetle killed a high percentage of the white spruce, but these trees were already severely or partially defoliated, and it may be assumed that many if not most of them would have died from the sawfly attack. Similar conditions occurred throughout a large part of the Peninsula (12). There was no serious mortality outside of the Gaspe, except in a few limited areas of which Parke Reserve and Young's Brook are examples.

\section{Mortality in Relation to Defoliation}

White spruce and black spruce withstood several years of almost complete loss of old needles as long as most of the new needles were intact. Tree mortality was therefore closely related to the severity of defoliation of new shoots and to twig mortality. In the Gaspe, feeding on the new needles was most 
severe in 1934 and 1935, but in subsequent years twig mortality gradually increased and had an effect similar to the destruction of new foliage.

The degree of defoliation necessary to kill trees was studied for mature dominant and co-dominant classes. Severe infestations of white spruce lasting four to seven years, and causing up to 90 per cent loss of old foliage and 50 per cent loss of new foliage, did not result in any appreciable tree mortality (Figure 3, A, B). However, severe infestations over a longer period (Figure $3, \mathrm{C}, \mathrm{E}, \mathrm{F}$ ) resulted in considerable mortality. Trees dying from defoliation had suffered an average loss of 95 per cent of the old foliage for several years and for at least three consecutive years of this period all the old foliage was absent or eaten. Also, they lacked at least 75 per cent of the normal amount of new growth as a result of direct feeding or twig mortality (Figure 3, C). Black spruce tended to die from rather less defoliation than the white spruce (Figure 3, E, F).

Mortality in Relation to Diameter

There is a relation between size of tree and mortality in both white spruce and black spruce. Data from cruise lines, on which all trees of 4.5 inches D.B.H. and over were tallied, showing that the percentage of mortality increased directly with diameter (Table I). However, smaller trees were often killed by the feeding of larvae that fell from severely defoliated spruce in the overstories.

TABLE I-Mortality by Diameter Classes of Trees killed by the Sawfly without Attack by the Eastern Spruce Beetle. Data from Cruise Lines in the Cascapedia District

\begin{tabular}{|c|c|c|c|c|c|}
\hline \multirow{2}{*}{$\begin{array}{l}\text { Species } \\
\text { of } \\
\text { Spruce }\end{array}$} & \multicolumn{5}{|c|}{ Mortality by diameter classes in inches } \\
\hline & $5-6$ & $7-8$ & $9-10$ & $11-12$ & $13 \&$ up \\
\hline & & & & & \\
\hline Number & 591 & 517 & 327 & 163 & 88 \\
\hline$\%$ Killed & 26 & 32 & 37 & 48 & 58 \\
\hline Number & 367 & 288 & 187 & 59 & 11 \\
\hline$\%$ Killed & 8 & 18 & 33 & 39 & 54 \\
\hline
\end{tabular}

Mortality by Years

The first mortality of white spruce from sawfly defoliation commenced about 1932 in the Cascapedia district. This was about seven years after the beginning of the attack. Although the outbreak ended rather abruptly in 1940 , a few trees continued to die as late as 1947, when observations terminated in this district. The peak of mortality occurred from 1936 to 1938 (Figure $3, \mathrm{C}, \mathrm{E}, \mathrm{F}$ ), and during this period as high as 10 per cent of the total trees were killed annually by the sawfly.

Total Mortality

The white spruce suffered the greatest amount of damage, the amount varying with the type. The mortality of white spruce was highest in the 
white spruce slope (Table II, C). The cruise data provide the best informaattacked by the beetle (Table II, A, B). The proportion of white spruce killed by the sawfly alone greatly exceeded that attacked by the beetle on the white spruce slope (Table II, C). The cruise data provide the best information on average conditions in the white spruce types. They show that 47 per cent of the volume of white spruce was killed by the combined effect of the sawfly and beetle (Table II, D). An additional 29 per cent of the white spruce died from defoliation alone.

The highest percentage of black spruce attacked by the beetle occurred on

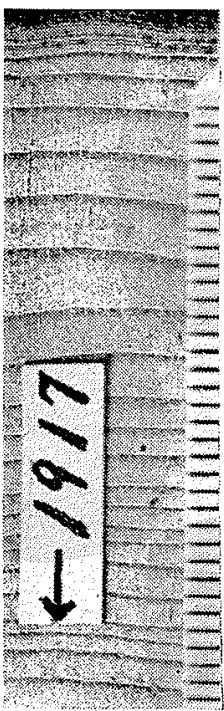

A

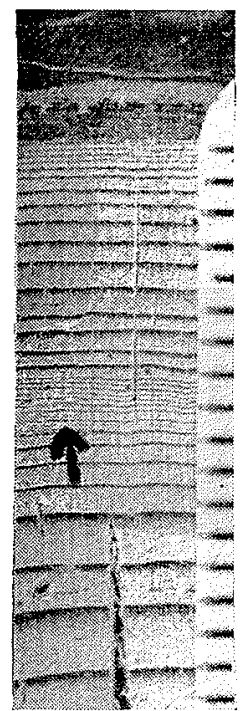

$\mathbf{B}$

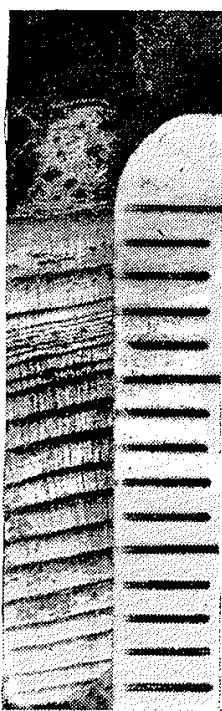

$\mathrm{C}$

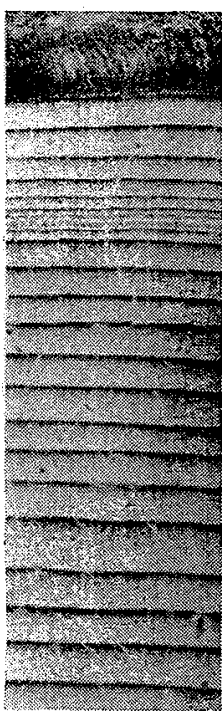

$\mathbf{D}$

Figure 4

Sections from white-spluce trees that recovered from the effects of defoliation by the European spruce sawfly. Scale in millimetres. A. Young's Brook, N.B.; note narrow ring in 1917 caused by budworm outbreak : tree cut in 1942; B, Young's Brook, N.B.; note incomplete rings in 1917 (arrow) and in 1921 caused by budworm and drought, respectively: tree cut in 1942; C, Young's Brook, N.I.; note rapid recovery; tree cut in 1946. D, Cascapedia, P.Q.; reduction of growth below average for this district, but recovery rapid; tree cut in 1946 .

the white spruce type on the flats, where nearly half of the trees that died had been attacked by both insects (Table II, A). In all other black spruce types beetle attack was negligible (Table II, E, F, G, H). The mortality of black spruce caused by the sawfly alone was highest in pure stands on the slopes (Table II, G) and lowest in pure black spruce stands on the flats (Table II, E, F). The most significant figures on the mortality of merchantable black spruce are those based on the cruise lines, which show that an average of 43 per cent of the volume of this species was lost as a result of sawfly attack (Table II, D). 


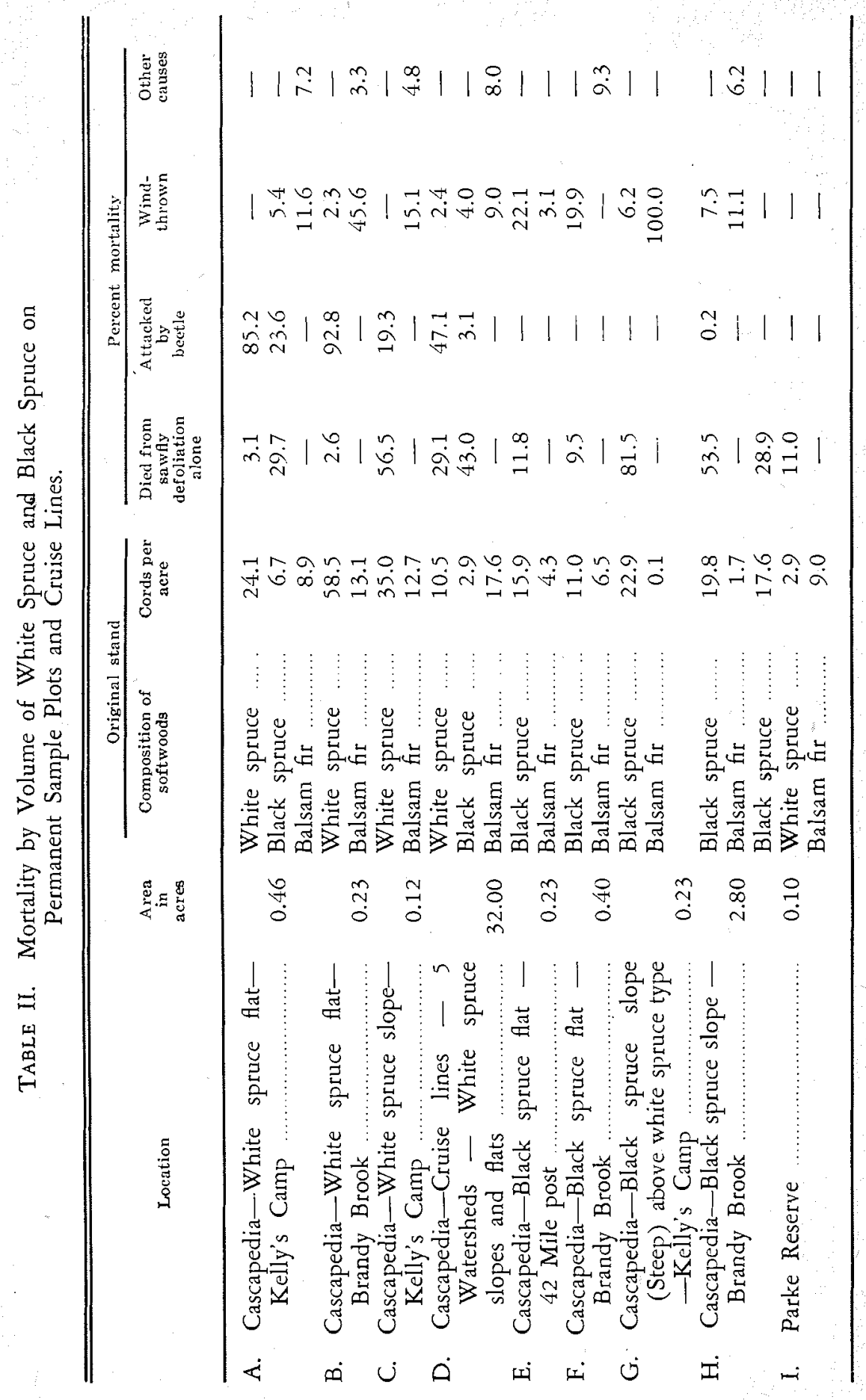


Gobeil (13) estimated the total stand of spruce in the Gaspe Peninsula in 1937 at $1,544,286,000$ cu.ft., which, at 90 cu.ft. per cord, amounts to about $17,158,700$ cords. He estimated that about 46 per cent of this volume had been killed by the sawfly and the beetle. This is an underestimate of the mortality, because his data were collected near the peak of the sawfly outbreak. Gobeil gave an estimate, however, of the additional volume of spruce that was likely to die, and by adding this figure to the volume killed by 1937 (see 13, Table II) his estimated mortality of 46 per cent in 1937 would be increased to about 68 per cent at the end of the outbreak.

This revised estimate is very, close to that obtained from the Cascapedia cruise lines, which show that about 66 per cent of the volume of spruce had been killed up to 1946. At this rate, the total loss of spruce as a result of sawfly and beetle attack would amount to approximately $11,300,000$ cords. This amount does not include losses from windfall or from the decadence of balsam fir. The percentages of mortality from these and other causes (Table II), applied to Gobeil's estimate of the total volume of spruce and balsam fir in the Gaspe, suggest additional estimated losses as follows: White spruce and black spruce, wind-thrown, 1,100,000 cords; balsam fir, windthrown, 2,052,000 cords; and balsam fir killed by other factors 1,824,000 cords. At least some of the mortality from windfall should be attributed to the sawfly outbreak, which resulted in the opening of the stands, and thereby increased the wind hazard. Such rough estimates neglect the possibility that there were areas where the mortality was less severe, but they do not include considrable losses due to the increment reduction on surviving trees.

\section{Change in Stand Composition}

A sample of 17 cruise lines was re-tallied in 1946 to show the change in stand composition after the sawfly outbreak. In addition to tallying the marked trees, smaller trees down to one-half inch D.B.H. were tallied. Also, seedling counts were made on 35 mil-acre plots. This provided some figures on spruce and balsam fir content of the residual stand and reproduction for comparison with the composition of the original stand. The original stand is represented by living trees and dead trees recorded in 1938 and those that died from 1938 to 1946 inclusive; the residual stand consists of all trees over 4.5 inches D.B.H. including those that came into this diameter class after the original tally; the advance growth refers to all unmarked trees over onehalf inch D.B.H.; and anything below this size is recorded as seedling growth.

The residual stands showed a considerable increase in the proportion of balsam fir and a decrease in the proportion of white spruce (Table III). The change in the proportions of these species was due to the severe mortality of white spruce and to the number of balsam fir trees that came into the merchantable class between 1938 and 1946. The percentage of black spruce decreased slightly from that shown in the original stand (Table III).

The percentage of balsam fir in the residual stand compared with the original stand has increased by about 10 per cent in number of stems and about 22 per cent by volume. These figures reflect the larger size of the dead spruce. The percentage of balsam ar in the advance and seedling growth 
is very similar to that in the residual stand, being slightly over 80 per cent, as compared with 70 per cent by stems in the original stand. This increased percentage of balsam fir may not be fully maintained to maturity in the next crop because of greater longevity and higher survival rate of the spruce. However, the effect of the outbreak has been to decrease the percentage of spruce in the next crop if it is cut as soon as it reaches pulpwood size. If left uncut the original percentage of spruce would probably be eventually restored.

TABLe III. Stand Composition per Acre, based on 17 Cruise Lines, and Proportion of Seedlings on 35 Mil-acre Plots.

\begin{tabular}{|c|c|c|c|c|c|c|c|c|}
\hline & \multirow[b]{2}{*}{$\begin{array}{l}\text { Total } \\
\text { stems }\end{array}$} & \multicolumn{3}{|c|}{ Percentages by stems } & \multirow{2}{*}{$\begin{array}{c}\text { Total } \\
\text { volume } \\
\text { in } \\
\text { cords }\end{array}$} & \multicolumn{3}{|c|}{ Percentages by volome } \\
\hline & & $\begin{array}{l}\text { White } \\
\text { spruce }\end{array}$ & $\begin{array}{c}\text { Black } \\
\text { Spruce }\end{array}$ & $\begin{array}{c}\text { Balsarn } \\
\text { fir }\end{array}$ & & $\begin{array}{c}\text { Percer } \\
\text { White } \\
\text { spruce }\end{array}$ & $\begin{array}{l}\text { ages by } \\
\text { Black } \\
\text { mpruce }\end{array}$ & $\frac{\substack{\text { Balame } \\
\text { fir }}}{}$ \\
\hline Original stand .. & 331 & 21.3 & 8.8 & 69.9 & 32.6 & 35.0 & 7.3 & 57.7 \\
\hline Stand in $1946 \ldots$ & 253 & 12.0 & 7.6 & 80.3 & 21.1 & 14.6 & 6.0 & 79.4 \\
\hline Advanced growth & 951 & 10.5 & 7.2 & 82.3 & - & - & - & - \\
\hline Seedlings $\quad \ldots \ldots \ldots . . .3$ & 9,900 & 8.5 & 9.5 & 81.9 & - & - & - & - \\
\hline
\end{tabular}

\section{SUMMARY}

The characteristics and effects of defoliation of spruce by the sawfly are described and compared with those of the spruce budworm.

Severe mortality was confined to the Gaspe, where the outbreak lasted eight to 15 years in some stands and was accompanied by an outbreak of the eastern spruce beetle during part of the period. In other areas in Quebec and in New Brunswick outbreaks lasted four to seven years.

Defoliation caused a gradual reduction in the width of the annual ring throughout the stem. This was greatest in the lower part. The effect of feeding in one year was shown in the ring of the following year. Reduction of growth was proportionate to the rate of growth before attack.

Surviving trees showed as many as four completely missing rings in the lower stem as well as several partial rings. None were missing in the top.

Loss of between 20 and 50 per cent of the old foliage was necessary to cause measurable reduction in the ring. Loss of all the old foliage and 75 . per cent or more of the new foliage was generally necessary to cause death.

Trees continued to die as many as seven years after defoliation ceased.

Total mortality in the Gaspe is estimated at about $11,400,000$ cords of spruce. Additional loss resulted from reduced growth on surviving trees and associated windfall. In the Cascapedia district it is estimated that the total volume was reduced in the white spruce type by about 12.5 cords per acre.

The proportion of balsam fir, by stems, was increased from about 70 . per cent in the original stand to about 80 per cent in the residual stand. The reproduction contained about 82 per cent balsam fr. 


\section{ACKNOWLEDGEMENTS}

The writers are indebted to R. E. Balch, who directed the studies and made helpful suggestions in interpreting results. R. F. Morris kindly provided information on frass-drop studies and assisted in other ways. Thanks are also expressed to L. J. Simpson, C. C. Smith, and others who were associated with the sawfly studies in the Gaspe Peninsula, and particularly to $M$. I. Prebble who was responsible for the field studies in that region from 1932 to 1939.

1. Balch, R. E. The spruce sawfly outbreak in 1936. Pulp and Paper Mag. Can., 38 (3) : 249-255. 1937.

2. Balch, R. E. Estimation of spruce sawfly hazard and need of salvage. Can. Dept. Agr., Div. Ent., and Can. Pulp and Paper Assoc. Joint Publication. 1938.

3. Balch, R. E. The outbreak of the European spruce sawfly in Canada and some important features of its bionomics. J. Econ. Ent. 32 (3): 412-418. 1939.

4. Balch, R. E. On the estimation of forest insect damage, with particular reference to Dendroctonus piceaperda Hopk. J. For. 40 (8) : 621-629. 1942.

5. Balch, R. E. European spruce sawfly in 1942. Pulp and Paper Mag. Can., 44 (2): 279-282. 1943.

6. Balch, R. E., F. T. Bird. A disease of the European spruce sawfly, Gilpinia hercyniae (Htg.), and its place in natural control. Sci. Agr. 25 (2): 65-80. 1944.

7. Craighead, F. C. Relation between mortality of trees attacked by the spruce budworm (Cacoecia fumiferana Clem.) and previous growth. J. Agr. Res. 30: 541-555. 1925.

8. Craighead, F. C. Some effects of artificial defoliation on pine and larch. J. For. 38 (11) : 885-888. 1940.

9. Daubenmire, R. F. An improved type precision dendrometer. Ecology 26: 97-8. 1945.

10. Evenden, J. C. Effects of defoliation by the pine butterfly upon ponderosa pine. J. For. 38 (12) : 949-956. 1940.

11. Fisher, R. A. Statistical methods for research workers. Oliver and Boyd. London. 1934.

12. Gobeil, A. R. Dommages causés aux forêts de la Gaspésie par les insectes. Province de Québec, Service d'Entomologie, Bull. 2. 1938.

13. Gobeil, A. R. Dendroctonus piceaperda Hopk.: A detrimental or beneficial insect? J. For. 39 (7): 632-640. 1941.

14. Graham, S. A. The effect of defoliation on tamarack. J. For. 29 (2): 199-206. 1931.

15. Martineau, R. Population studies of the European spruce sawfly (Gilpinia hercynide Htg.) in Quebec. For. Chron. 19 (2) : 3-23. 1943.

16. Morris, R. F. Frass-drop measurement in studies of the European spruce sawlly. University of Michigan, School of Forestry and Conservation. Bull. 12. Ann Arbor, Mich. 1949. 
17. Swaine, J. M. The control of the destructive spruce bark beetle in Eastern Canada. Dom. Canada Dept. Agr. Pamphlet 48. 1924.

18. Swaine, J. M., F. C. Craighead, and L. W. Bailey. Studies on the spruce budworm (Cacoecia fumiferana Clem.). Dom. of Canada Dept. Agr. Tech. Bull. 37, New Series. 1924. 